\title{
JAPONIA
}

Karol Żakowski

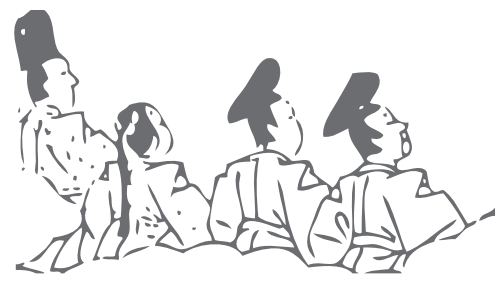

\section{ZNIESIENIE FRAKCYJNOŚCI W JAPOŃSKIEJ PARTII LIBERALNO-DEMOKRATYCZNEJ: STARE ZADANIE W NOWYCH CZASACH}

Japońska Partia Liberalno-Demokratyczna (PL-D) dostarcza jednego z najbardziej charakterystycznych przykładów frakcyjności. Właściwie można ją nazwać związkiem frakcji rywalizujących ze sobą o władzę w partii. Przewodniczenie PL-D jest zresztą niemal równoznaczne z rządami w całym państwie. Od powstania w 1955 r. partia ta sprawowała władzę prawie nieprzerwanie, zaś frakcyjność była jednym z czynników umacniających jej dominujący charakter na japońskiej scenie politycznej.

Japońska opinia publiczna zawsze bardzo krytycznie oceniała istnienie frakcji w łonie PL-D, uważając je za główną przyczynę korupcyjnych powiązań jej działaczy ze światem biznesu. Partia odpowiadała na te zarzuty cyklicznymi próbami zniesienia frakcyjności. Były to zarówno działania na rzecz odgórnego usuwania wewnętrznych podziałów, jak też zlikwidowania ich głównych przyczyn: systemu średnich okręgów wyborczych, sposobu wybierania przewodniczącego oraz zasad finansowania partii.

W związku z podejmowanymi właściwie od chwili powstania partii działaniami na rzecz zniesienia frakcyjności, należy się zastanowić, na ile były one motywowane rzeczywistą chęcią wykorzenienia patologii z japońskiego życia politycznego, na ile zaś ukrytymi interesami poszczególnych polityków. Na tle tej analizy będzie można ocenić niedawne reformatorskie starania premiera Koizumiego Jun'ichirō i jego następców: Abe Shinzō oraz Fukudy Yasuo. Zmiana ordynacji wyborczej w 1994 r. stworzyła nowe warunki dla dążeń reformatorskich. Czy jednak wprowadzenie jednomandatowych okręgów wyborczych rzeczywiście osłabiło frakcyjność w PL-D? 


\section{Ciemna i jasna strona frakcyjności w PL-D}

Pogląd, że frakcyjność to główna przyczyna patologii w życiu politycznym jest bardzo rozpowszechniony w Japonii. Najważniejszym instytucjonalnym uwarunkowaniem frakcyjności był obowiązujący do 1994 r. system nieprzechodniego głosu i okręgów wyborczych średniej wielkości ${ }^{1}$. W jednym okręgu wybierano od dwóch do sześciu członków izby niższej parlamentu (Shūgiin). Partia chcąca zdobyć większość w parlamencie musiała wystawiać w poszczególnych okręgach po kilku kandydatów, ryzykując tym samym rozproszenie głosów własnego elektoratu. Jedynym ugrupowaniem na tyle potężnym, by podjąć takie wyzwanie, była PL-D. Należący do różnych frakcji kandydaci PL-D w naturalny sposób rywalizowali głównie ze sobą o głosy elektoratu własnej partii. Właśnie rywalizacja wyborcza leżała u podstaw frakcyjności. Szefowie frakcji w zamian za wsparcie udzielane szeregowym politykom w kampanii wyborczej oraz przy rozdziale stanowisk partyjnych i państwowych mogli liczyć na ich lojalność przy wyborze przewodniczącego PL-D, dokonywanym głównie w gronie należących do partii parlamentarzystów. Taki system miał jednak swoje ciemne strony: efektywne zwiększanie wpływów frakcji było możliwe m.in. dzięki korupcyjnym powiązaniom ze światem biznesu, zaś skupione tylko na powiększaniu własnych szeregów grupy wewnątrzpartyjne opierały się nie tyle na konkretnej jedności programowej, co na osobistych kontaktach ludzi władzy.

W PL-D można wyróżnić frakcje „głównego nurtu” (shuryūha), spełniające rolę wewnątrzpartyjnej koalicji i obsadzające najbardziej pożądane stanowiska partyjne i państwowe, oraz „poza głównym nurtem” (hishuryūha), czyli takie, które przegrały rywalizację o fotel przewodniczącego partii. Oczywiście, źródłem siły frakcji i możliwości kreowania własnego „głównego nurtu” jest jej wielkość liczona $\mathrm{w}$ deputowanych obu izb parlamentu. Z kolei aby przyciagnąć nowych członków oraz zapewnić własnym kandydatom zwycięstwo w ich okręgach wyborczych, potrzeba dużych pieniędzy. Często były one dostarczane przez wielkie przedsiębiorstwa w zamian za pozytywne dla nich decyzje administracji państwowej.

Właściwie każda frakcja miała swoje własne korupcyjne powiązania z określonymi środowiskami biznesowymi. Można tu wymienić szczególnie monopo-

${ }^{1}$ Uwarunkowania instytucjonalne nie były jednak jedynymi przyczynami uformowania się frakcji w PL-D. Równie ważną rolę odgrywały czynniki kulturowe. Związki pomiędzy patronem (oyabun) a klientem (kobun) są głęboko zakorzenione w japońskim społeczeństwie „wertykalnym”. Szerzej na ten temat zob. Nakane Chie, Tate shakai no ningen kankei [Stosunki międzyludzkie społeczeństwa wertykalnego], Kōdansha, Tokio 2007, s. 133-135. (Stosujemy tu szyk japoński: nazwisko i imię). 
lizację spraw dotyczących polityki budownictwa przez dawną frakcję Tanaki Kakueia czy transportu przez dawną frakcję Mitsuzuki Hiroshi. Nawet uważana za „czystą" frakcja Mikiego Takeo straciła ten korzystny wizerunek pod przewodnictwem Kōmoto Toshio, który był związany z zajmującą się transportem morskim firmą Sankō Kisen².

Najbardziej z praktyk korupcyjnych słynęło obecne Heisei Kenkyūkai (przewodniczący Tsushima Yūji), dawna frakcja Satō Eisaku, Tanaki Kakuei'a, Takeshity Noboru (Keiseikai), Obuchi Keizō i Hashimoto Rytūarō. To właśnie z nią związane były głośne skandale firm Lockheed, Recruit czy Sagawa Kyūbin. Szczególnie na przełomie lat 80. i 90. wykształcił się swoisty triumwirat polityków tej frakcji: byłego premiera Takeshity Noboru, Kanemaru Shina i sekretarza generalnego PL-D Ozawy Ichirō, którzy zza kulis sprawowali pełnię władzy nad państwem (tzw. konchikushō). Już znacznie wcześniej jednak Kanemaru Shin zdołał stworzyć sprawny mechanizm wyłudzania pieniędzy od przedsiębiorców ze swojej rodzimej prefektury Yamanashi. Do założonego przez niego stowarzyszenia Kenshinkai należało 90 proc. lokalnych firm budowlanych, które konkurowały w potajemnych aukcjach o prawo wręczenia łapówki. Oprócz tego obowiązkowe były opłaty przy okazji każdych wyborów parlamentarnych ${ }^{3}$. Podobny system stworzył w prefekturze Shimane Takeshita Noboru ${ }^{4}$.

Frakcje są raczej grupami towarzysko-biznesowymi niż platformami programowymi. Głównym celem jest zdobycie i utrzymanie władzy, a nie realizacja określonego programu politycznego. Owszem, widać pewne różnice ideologiczne między frakcjami, ale zazwyczaj nie miały one decydującego wpływu na tworzenie „głównego nurtu” wewnątrz partii. Obok spójnych ideologicznie sojuszy w ramach obozu liberalnego czy konserwatywnego, w PL-D dochodziło także do zaskakujących strategicznych koalicji pomiędzy frakcjami należącymi do przeciwstawnych skrzydeł ideologicznych. Ostatecznie najważniejsza była więc rywalizacja o stanowiska partyjne i państwowe.

Można jednak zadać pytanie, czy frakcyjność w PL-D ma same negatywne strony? Według Honzawy Jirō jest ona zjawiskiem pozytywnym, ponieważ zapewnia wewnątrzpartyjną demokrację. Jak napisał: Poprzez rywalizację między frakcjami PL-D odnawia swoja tkankę. Odrzucajac zepsute komórki, tworzy nowe ${ }^{5}$. To właśnie frakcyjność ma być źródłem siły partii dominującej. Istnienie wewnątrzpartyjnej

${ }^{2}$ Honzawa Jirō, Ura kara mita Jimintō habatsu [Frakcje Partii Liberalno-Demokratycznej widziane zza kulis], Eeru Shuppansha, Tokio 1993, s. 72.

${ }^{3}$ Itō Hirotoshi, Konchikushō no kane to kenryoku [Pieniądze oraz władza Kanemaru, Takeshity i Ozawy], Shakai Shinpō, Tokio 1993, s. 12.

${ }^{4}$ Ibidem, s. 23.

5 Honzawa Jirō, op.cit., s. 28. 
opozycji gwarantuje swobodę wymiany poglądów i spełnia niezwykle ważną rolę kontroli władzy. Negatywna ocena rządu przez opinię publiczną może np. skutkować przesileniem rządowym, wywołanym przez walczące o władzę frakcje ${ }^{6}$. Jasną stronę frakcyjności ujął niegdyś metaforycznie Ōhira Masayoshi: Różnorodne instrumenty muzyczne, zachowujac własna wyjatkowość, tacza organicznie cała gamę tonów i tworzq wyśmienity chór, mogacy grać symfonię. Powstaje wówczas melodia nieporównywalnie lepsza od tonu samych tylko skrzypiec ${ }^{7}$.

Według Honzawy Jirō korupcyjne powiązania polityki i biznesu wynikają nie tyle z samej frakcyjności, co z nadmiernego rozrostu grup wewnątrzpartyjnych. Jak stwierdził kolokwialnie były marszałek Izby Reprezentantów Tamura Hajime: Po przekroczeniu liczby trzydziestu osób trzeba robić straszne rzeczy. Wedtug obecnego systemu można zbierać dowolna ilość składek politycznych. Jeśli się z tego skorzysta, gromadzone sq także złe pieniqdze $e^{8}$. Szczególnie niebezpieczna była sytuacja, gdy jedna z frakcji osiagnęła zdecydowaną przewagę nad pozostałymi. Zgodnie ze słowami Hashimoto Tomisaburō, sekretarza generalnego PL-D w czasie kadencji Tanaki Kakuei: Kontrolujac jednq czwarta parlamentarzystów, ustanawia się władze $e^{9}$. Z kolei według Iseri Hirofumi, nie wystawiając własnego kandydata na szefa partii, wystarczy jedynie jedna ósma parlamentarzystów do pełni władzy nad państwem ${ }^{10}$.

Taki nienaturalny stan panował od początku lat 80. do 1993 r., kiedy starający się oczyścić z zarzutów korupcyjnych Tanaka Kakuei, a później Takeshita Noboru, zwiększyli liczebność swojej frakcji do poziomu wcześniej nieznanego. U szczytu potęgi $\mathrm{w}$ drugiej połowie lat 80 . należało do niej blisko 140 parlamentarzystów. W takich warunkach doszło do zaburzenia normalnej rywalizacji wewnątrzpartyjnej i „ogólnego ukoalicyjnienia” (sōyotōka) praktycznie wszystkich frakcji w PL-D. Tanaka Kakuei, a po 1989 r. także Takeshita Noboru, rezygnując z wystawiania własnego kandydata na stanowisko przewodniczącego partii, mogli dowolnie mianować na premiera przedstawiciela jakiejś innej frakcji, który w naturalny sposób stawał się marionetką w ich rękach. Ponieważ pozostałe frakcje nie miały możliwości sprzeciwienia się takiemu układowi, były przymuszone do uczestniczenia w „ogólnym głównym nurcie” (sōshuryū), który uformował się pod przywództwem Takeshity Noboru, Kanemaru Shina i Ozawy Ichirō. W praktyce oznaczało to zanik pełnionej przez frakcje kontroli rządzących

${ }^{6}$ Ibidem, s. 39-40.

${ }^{7}$ Iseri Hirofumi, Habatsu saihensei. Jimintō seiji no omote to ura [Reorganizacja frakcji. Jawne i ukryte oblicze polityki Partii Liberalno-Demokratycznej], Chūō Kōronsha, Tokio 1988, s. 189.

${ }^{8}$ Honzawa Jirō, op.cit., s. 116.

9 Iseri Hirofumi, op.cit., s. 170.

${ }^{10}$ Ibidem, s. 170-171. 
i niepożądane w demokratycznym społeczeństwie skupienie władzy w ręku przywódcy największej frakcji.

Nawet jeśli się uzna sądy Honzawy Jirō za przesadzone, frakcyjność była naturalnym stanem w PL-D, zaś wszelkie próby jej zniesienia nosiły znamiona odgórnej „,inżynierii partyjnej”. Tak naprawdę wymuszona reforma frakcyjności jest niemożliwa w warunkach demokratycznych, gdyż negowałaby wolność zrzeszania się. Chociaż podział na frakcje może gwarantować swobodną wymianę poglądów i zmianę władzy, jednak w przypadku systemu partii dominującej zawsze będzie to tylko „sztuczna zmiana władzy” (gijiteki seiken kōtai) pomiędzy w dużym stopniu bezprogramowymi grupami wewnątrzpartyjnymi, a nie partiami reprezentującymi różne skrzydła japońskiej sceny politycznej.

\section{Próby reformy w przeszłości}

Jak miał powiedzieć Tanaka Kakuei: Zostawszy premierem, chce się choć raz spróbować obwieścić rozwiazanie frakcji ${ }^{11}$. Charakterystyczne są też słowa Kishiego Nobusuke: 70 proc. energii muszę przeznaczać na problemy wewnatrzpartyjne. Na wykonywanie polityki rzadu moge poświęcić tylko pozostate 30 proc. $^{12}$. Własna frakcja jest dla jej przywódcy narzędziem służącym do zdobycia stanowiska przewodniczącego partii. Kiedy mu się już to powiedzie, system frakcyjny zaczyna bardziej przeszkadzać niż pomagać w sprawowaniu władzy, dlatego zazwyczaj to właśnie premierzy podejmowali próby reformy wewnątrzpartyjnej, choć zdarzały się także inicjatywy oddolne. Najczęściej zresztą i jedne, i drugie były bardziej elementem rywalizacji o władzę niż szczerym usiłowaniem usunięcia patologii życia politycznego. Oczywiście sporą rolę odgrywała także dbałość o wizerunek partii w społeczeństwie, więc nie było przypadkiem, że pomysły reformy odżywały szczególnie po głośnych skandalach korupcyjnych.

Dyskusja o szkodliwości podziałów frakcyjnych w PL-D pojawiła się niemal na samym początku jej istnienia. Pierwszym premierem, który naprawdę próbował usunąc podziały wewnątrzpartyjne, był rządzący w latach 1957-1960 Kishi Nobusuke. Jak zwykł mawiać: Rozwiqzanie frakcji to glos Nieba ${ }^{13}$. Część stronników Kishiego rzeczywiście w symboliczny sposób zdjęła tabliczki

${ }^{11}$ Honzawa Jirō, Jimintō habatsu [Frakcje Partii Liberalno-Demokratycznej], Piipurusha, Tokio 1990, s. 46.

${ }_{12}$ Tsuchiya Shigeru, Jimintō habatsu kōbōshi [Historia wzlotu i upadku frakcji Partii LiberalnoDemokratycznej], Kadensha, Tokio 2000, s. 21.

${ }^{13}$ Uchida Kenzō, Habatsu. Seiken kōsō no omote to ura [Frakcje. Jawne i ukryte oblicze rywalizacji o władzę], Kōdansha Gendai Shinsho, Tokio 1983, s. 68. 
z gabinetów frakcyjnych, jednak nie podporządkowali się temu odgórnemu nakazowi ani należący do ,głównego nurtu” Satō Eisaku, ani członek, ,przeciwnego nurtu" Ikeda Hayato. Jak twierdzi Uchida Kenzō, było to przejawem instynktu samozachowawczego tych dwóch polityków, dążących do uzyskania w przyszłości stanowiska premiera ${ }^{14}$. Według Honzawy Jirō rozwiązanie frakcji tak naprawdę nie było dla Kishiego celem, a jedynie środkiem, który ułatwiłby mu zmianę konstytucji i remilitaryzację kraju. Reforma wewnątrzpartyjna miała być pierwszym krokiem do odejścia od „doktryny Yoshidy"15. Wszakże frakcyjność w dużym stopniu opierała się na podziale na „główny nurt konserwatywny” (hoshu honryū) dawnej Partii Liberalnej (Ikeda Hayato i Satō Eisaku) oraz „,boczny nurt konserwatywny” (hoshu bōry $\bar{u}$ ), tworzony przez byłych członków Partii Demokratycznej (Kishi Nobusuke, Kōno Ichirō, Miki Takeo). Pierwszy z tych obozów był w naturalny sposób utożsamiany z ideami Yoshidy Shigeru, a nawet w drugim znajdowała się pacyfistyczna frakcja Mikiego Takeo. Kishi Nobusuke jedynie poprzez rozbicie niekorzystnego dla siebie układu frakcyjnego i skupienie władzy we własnych rękach mógłby liczyć na dyscyplinę partyjną i przegłosowanie przez parlament poprawek do konstytucji ${ }^{16}$.

Z kolei za kadencji Ikedy Hayato (1960-1964) hasło zniesienia frakcyjności zostało podniesione zarówno przez premiera, jak i frakcje ,przeciwnego nurtu”. Ikeda pragnął unowocześnienia struktur partyjnych i racjonalizacji pozyskiwania funduszy, gromadzonych w rękach szefów frakcji. W tym celu stworzono w $1961 \mathrm{r}$. Stowarzyszenie Ludowe (Kokumin Kyōkai), które miało pozyskiwać kapitał od osób prywatnych i przedsiębiorców. Poza tym poprzez Komisję ds. Badań nad Organizacją Partii (Tō Soshiki Chōsakai) zaczęto kreślić śmiałe pomysły zniesienia frakcji. Okazało się jednak, że zanim plany te nabrały konkretnych kształtów, retoryka reformy posłużyła coraz bardziej krytycznym wobec premiera frakcjom Satō i Kishiego do ataku na Ikedę. Następca idei Kishiego, Fukuda Takeo, utworzył w 1962 r. Klub Odnowy Oblicza Partii (Tōfū Sasshin Kondankai), później przemianowany na Sojusz Odnowy Oblicza Partii: (Tōfū Sasshin Renmei) i zażądał gruntownej reformy PL-D. W ten sposób, jak napisał Iyasu Tadashi: Unowocześnienie partii i rozwiazanie frakcji zostaty paradoksalnie wykorzystane w rywalizacji międzyfrakcyjnej ${ }^{17}$.

${ }^{14}$ Ibidem, s. 68-69.

15 „Doktryna Yoshidy” głosiła oparcie dyplomacji japońskiej o przymierze z USA, rezygnację z militarnych ambicji mocarstwowych i skupienie się na rozwoju gospodarczym.

${ }^{16}$ Potrzeba do tego było dwóch trzecich głosów członków obu izb parlamentu. Poza tym zmiana konstytucji musiałaby być zatwierdzona w referendum, biorąc zaś pod uwagę pacyfistyczne nastroje społeczne, nie było na to szansy w okresie zimnowojennym.

${ }_{17}$ Iyasu Tadashi, Seitō habatsu no shakaigaku. Taishū minshusei no nihonteki tenkai [Socjologia frakcji politycznych. Japoński rozwój systemu demokracji masowej], Sekai Shisōsha, Kioto 1983, s. 167. 
Pragnąc przejąć inicjatywę, Ikeda Hayato powołał wówczas na stanowisko przewodniczącego Komisji Badań ds. Organizacji Partii Mikiego Takeo, powierzając mu misję unowocześnienia struktur PL-D. Jeśli o jakimś polityku można by powiedzieć, że nie kierował się partykularnym interesem, ale szczerą chęcią wyeliminowania patologicznych następstw frakcyjności, to właśnie o Mikim. Ten zdeklarowany pacyfista, powszechnie nazywany „czystym Miki”, energicznie przystapił do kreślenia projektu zmian. Postulaty reformy przedstawił w swoim sławnym raporcie z 1963 r. (Miki tōshin). Dotyczyły one przede wszystkim bezwarunkowego rozwiązania frakcji, przyznawania stanowisk według predyspozycji, a nie chęci zachowania równowagi międzyfrakcyjnej, a także ujednolicenia funduszy partyjnych. Chcąc wykorzystać retorykę reformy dla umocnienia własnej władzy i ukrócenia rewolty „przeciwnego nurtu”, Ikeda, który jeszcze za kadencji Kishiego odmówił rozwiązania swojej frakcji, uczynił to w październiku 1963 r., wywierając presję na pozostałe grupy. Wkrótce też przestały istnieć frakcje Mikiego, Ishiiego, Fukudy, Kōno i Ōno. Okazało się jednak, że o ile symbolicznie zdjęto plakietki z nazwami grup z drzwi ich biur, to więzi personalne były trwałe i frakcje odrodziły się przy okazji następnych wyborów przewodniczącego partii ${ }^{18}$.

Problem reformy wewnątrzpartyjnej przycichł nieco za długich rządów Satō Eisaku (1964-1972), choć i on z początku próbował wykorzystać ją dla własnych celów. W 1965 r. ogłosił rozwiązanie swojej frakcji, ale nie posłużyło to za wzór dla innych grup. Zresztą Satō nie musiał walczyć z rywalami, używając do tego retoryki reformy ze względu na śmierć głównych oponentów i związane z tym osłabienie konkurencyjnych frakcji ${ }^{19}$. Problem reformy powrócił za to z pełną mocą w latach 70. w następstwie krytyki premiera Tanaki Kakuei (1972-1974) za prowadzoną przez niego ,politykę pieniądza” (kinken seiji). Był to okres zaciętej rywalizacji politycznej między Tanaką a Fukudą Takeo (tzw. wojna Kaku-Fuku).

Gdy w 1974 r. krytykowany za pozyskiwanie poparcia politycznego poprzez łapówki Tanaka Kakuei musiał ustąpić z fotela premiera, wiceprzewodniczący partii Shiina Etsusaburō wyznaczył na nowego przewodniczącego Mikiego Takeo. Krok ten miał na celu poprawienie wizerunku PL-D wśród społeczeństwa. Miki, już jako premier, mógł powrócić do własnych planów zmian sformułowanych ponad dziesięć lat wcześniej. Udało mu się doprowadzić do uchwalenia dwóch ważnych ustaw: $\mathrm{w}$ sprawie wyborów na urzędy publiczne oraz ograniczeń w finansowaniu partii przez przedsiębiorców. Zgodnie z tą ostatnią, ustanowiono górną granicę datków na $100 \mathrm{mln}$ yenów rocznie od pojedynczego przedsiębiorcy. Nie wyeliminowało to jednak przyczyn korupcji, a tylko zmusiło frakcje do dostosowania

18 Ibidem, s. 169.

19 Ibidem, s. 237-238. 
się do nowej sytuacji. Odtąd zamiast przyjmować duże wpłaty od zaledwie kilku wielkich przedsiębiorstw, politycy musieli jeszcze energiczniej zabiegać o więcej mniejszych składek od licznych ludzi biznesu ${ }^{20}$.

Reformy wywołały mimo wszystko niezadowolenie frakcji ,przeciwnego nurtu” (Tanaki, Fukudy i Ōhiry), stanowiących większość w partii, a nawet samego Shiiny Etsusaburō. Paradoksalnie, przeciwnicy Mikiego użyli do jego obalenia retoryki reformy. Założywszy Radę Ustanowienia Systemu Solidarnej Partii (Kyotō Taisei Kakuritsu Kyōgikai), mającą za cel m.in. rozwiązanie frakcji, zażądali dymisji premiera $^{21}$. Miki odmówił, jednak wkrótce musiał stawić czoło zbliżającym się wyborom do izby niższej parlamentu. Po aferze firmy Lockheed ${ }^{22}$ i przy narastających tarciach wewnętrznych PL-D nie mogła osiagnąć dobrego wyniku. Chociaż sam Miki Takeo cieszył się poparciem społecznym, wziął odpowiedzialność za porażkę wyborczą i podał się do dymisji.

Kiedy w 1976 r. do władzy doszedł Fukuda Takeo, tryumfalnie ogłoszono rozwiązanie frakcji. Do 1977 r. zdjęto z ich biur tabliczki z dotychczasowymi nazwami, zaś środki masowego przekazu zaczęły mówić o „byłych” frakcjach Fukudy, Tanaki czy Ōhiry. Premier dokładał wszelkich starań, aby tym razem reforma była trwała. Ponieważ wraz z zamknięciem biur frakcyjnych posłowie utracili miejsca do wymiany poglądów, Fukuda stworzył pokoje spotkań dla reprezentantów poszczególnych regionów oraz Klub Wolności (Ribaruti Kurabu) jako izbę luźnych spotkań wszystkich polityków z PL-D, niezależnie od ich wcześniejszej przynależności frakcyjnej ${ }^{23}$. Wszystkie te zabiegi okazały się jednak nieskuteczne, ponieważ grupy wewnątrzpartyjne odrodziły się przy okazji kolejnych wyborów.

Zorganizowane po raz pierwszy w 1978 r. wybory przewodniczącego PL-D spośród wszystkich członków i sympatyków partii były elementem reformy wewnątrzpartyjnej, postulowanym jeszcze przez Mikiego Takeo. Okazało się jednak, że upublicznienie sposobu elekcji tej najważniejszej w państwie osoby nie stało się bodźcem do rozwiązania frakcji, jak się spodziewano, ale wręcz zaostrzyło rywalizację międzyfrakcyjną. Prawo głosu mieli wszyscy członkowie PL-D, którzy od 2 lat płacili składkę 1,5 tys. yenów oraz ci spośród sympatyków partii (członków Liberalnego Zgromadzenia Ludowego, Jiyu Kokumin Kaigi), którzy do trzech miesięcy przed wyborami wpłacili 10 tys. yenów. Tysiąc głosów

${ }^{20}$ Iseri Hirofumi, op.cit., s. 74-75.

${ }^{21}$ Iyasu Tadashi, op.cit., s. 266-269.

22 W 1976 r. ujawniono, że premier Tanaka przyjął łapówkę od firmy Lockheed.

${ }^{23}$ Fukuda Takeo, Watashi no rirekisho [Mój życiorys], [w:] Kishi Nobusuke, Kōno Ichirō, Fukuda Takeo, Gotōda Masaharu, Tanaka Kakuei, Nakasone Yasuhiro, Watashi no rirekisho. Hoshu seiken no ninaite [Mój życiorys. Osoby odpowiedzialne za władzę konserwatywną], Nihon Keizai Shinbun Shuppansha, Tokio 2007, s. 198-199. 
w tych ,prawyborach” przekładało się na jeden głos w zgromadzeniu, na którym parlamentarzyści z PL-D wybierali przewodniczącego. Liczono na to, że dzięki temu rozgorzeje rzeczywista debata publiczna na temat kandydatów i wybór nie będzie tylko kwestią strategicznego układu między frakcjami. Okazało się jednak, iż poszczególne frakcje zwiększyły wysiłki w celu rekrutacji nowych sympatyków partii, do czego potrzebne były ogromne fundusze. Spodziewający się łatwego zwycięstwa Fukuda Takeo został pokonany w prawyborach przez Ōhirę Masayoshi, ponieważ za Ōhirą stał posiadający najlepsze kontakty ze światem biznesu Tanaka Kakuei. W ten sposób zmiana sposobu wybierania przewodniczącego PL-D tylko rozszerzyła wpływy frakcji wśród szeregowych członków partii i pogłębiła „,politykę pieniądza" 24 .

Jak widać, pomimo usilnych starań wpływowych polityków PL-D, po każdorazowym obwieszczeniu rozwiązania frakcji te po jakimś czasie odradzały się jak feniks z popiołów. Działo się tak dlatego, że zazwyczaj chciano od razu wyeliminować skutek, jakim była frakcyjność, zamiast jego przyczyny. Głównym bodźcem wymuszającym frakcyjność w PL-D był, poza sposobem wybierania przewodniczącego i zbierania funduszy partyjnych, system średnich okręgów wyborczych. Nic dziwnego, że z czasem gruntowna zmiana ordynacji wyborczej stała się głównym dążeniem polityków głoszących konieczność reform. Co prawda projekt ustawy wprowadzającej system jednomandatowych okręgów wyborczych został przygotowany już za rządów pierwszego premiera z PL-D, Hatoyamy Ichirō. Gorącym zwolennikiem małych okręgów wyborczych był także Tanaka Kakuei, pragnący poprzez nowy system polepszyć wyniki PL-D i zwiększyć władzę centralnych organów partii, na których czele wówczas stał. Oczywiste było jednak, że za każdym razem, gdy przewodniczący PL-D będzie próbował dokonać tak rewolucyjnych zmian, spotka się ze zdecydowanym sprzeciwem polityków z własnej partii, przyzwyczajonych do skostniałego systemu.

\section{Zmiana systemu wyborczego}

Seria skandali korupcyjnych na przełomie lat 80. i 90 . XX w. ponownie wymusiła na PL-D poważną dyskusję na temat wad frakcyjności i konieczności usunięcia jej strukturalnych przyczyn. Jednak pomimo utraty zaufania społecznego i zaczynającego się w $1991 \mathrm{r}$. kryzysu gospodarczego, partia nadal nie była w stanie przeprowadzić gruntownych reform. Wysiłki premierów Kaifu Toshiki i Miyaza-

${ }^{24}$ Iyasu Tadashi, op.cit., s. 287-288. 
wy Kiichi spełzły na niczym wobec wewnątrzpartyjnej opozycji. W końcu doszło do tego, że ociagającą się ze zmianami PL-D wyręczyły inne siły polityczne.

Afery firm Recruit w 1988 r. i Sagawa Kyūbin w 1992 r. spowodowały, że podział PL-D na dwa obozy, czyli zwolenników i przeciwników reform, stawał się coraz bardziej wyraźny. Linia podziału w większym stopniu pokrywała się z tarciami międzypokoleniowymi niż między frakcjami. Młodsi parlamentarzyści relatywnie bardziej popierali zmiany niż ich starsi koledzy. Z drugiej strony hasło reform, podobnie jak w przeszłości, stało się raczej narzędziem rywalizacji o władzę i realizacji własnych interesów, niż celem samym w sobie. Widać było zresztą wyraźnie, że główni propagatorzy zmian nie należeli do polityków pokroju ,czystego Mikiego".

Stojący na czele zwolenników reform (kaikaku suishinpa) Ozawa Ichirō od lat czerpał korzyści z powiązań ze światem biznesu. Był zresztą bliskim współpracownikiem Kanemaru Shina, aresztowanego po wyjściu na jaw afery Sagawa Kyūbin. Utraciwszy potężnego patrona, Ozawa rozpoczął walkę o sukcesję we frakcji Takeshity Noboru (Keiseikai). Hasła reformy okazały się idealnym środkiem „ataku wyprzedzającego" w obliczu narastającej krytyki kierowanej wobec zaufanych ludzi Kanemaru. W końcu walkę o władzę we frakcji wygrał Obuchi Keizō, wspierany przez Kajiyamę Seiroku, zaś Ozawa założył własną grupę razem z Hatą Tsutomu. Ponieważ środowisko Kajiyamy zwlekało z reformą systemu wyborczego, frakcja Haty zaczęła je ostro krytykować jako siedlisko konserwatystów (shukyūha). Ostatecznie Hata z Ozawą opuścili PL-D, zakładając Partię Odnowy (Shinseitō), zaś hasło reform okazało się idealnym spoiwem utworzonej wkrótce koalicji ośmiu partii, które odsunęły PL-D od władzy w 1993 r. W rządzie Hosokawy Morihiro, a tym bardziej Haty Tsutomu, prawdziwą władzę sprawował Ozawa Ichirō.

Pojawia sięjednak wątpliwość, czy hasła reformy były dla Ozawy tylko elementem strategii politycznej, czy także środkiem do realizacji bardziej dalekosiężnego celu. Według Okushima Sadao, tacy znani propagatorzy wprowadzenia systemu jednomandatowych okręgów wyborczych, jak Gotōda Masaharu czy Itō Masayoshi, kierowali się chęcią wyeliminowania przyczyn korupcji, natomiast Ozawa miał przed oczyma stworzenie systemu dwupartyjnego ${ }^{25}$. Sam Ozawa w swoim bestsellerze z 1993 r. Plan przebudowy Japonii (Nippon kaizō keikaku) wymieniał liczne zalety wprowadzenia okręgów jednomandatowych, przede wszystkim zdynamizowanie japońskiej polityki i umożliwienie rzeczywistej zmiany władzy ${ }^{26}$. Podkreślał jednocześnie, że reforma ordynacji wyborczej nie jest celem samym w sobie.

${ }^{25}$ Okushima Sadao, Jimintō Kanjichōshitsu no 30 nen [30 lat Biura Sekretariatu Generalnego Partii Liberalno-Demokratycznej], Chūō Kōron Shinsha 2005, s. 277-278.

${ }^{26}$ Ozawa Ichirō, Nippon kaizō keikaku [Plan przebudowy Japonii], Kōdansha, Tokio 2006, s. 69. 
Za cel ostateczny uważał, poza ukróceniem korupcji, stworzenie systemu jednolitej partii z silną władzą centralną, który przeciwstawiał „zarazie frakcji” (habatsu no heigai $)^{27}$. Pod tym względem starania Ozawy przypominały dazżenia Kishiego, Ikedy czy Fukudy do wyeliminowania wewnątrzpartyjnej opozycji. Z kolei według Honzawy Jirō, przyświecał mu przede wszystkim ten sam cel, co Kishiemu Nobusuke, czyli zmiana konstytucji ${ }^{28}$. Ozawa Ichirō rzeczywiście jest gorącym zwolennikiem dostosowania japońskiej ustawy zasadniczej do realiów po czasach zimnej wojny i uczynienia z Japonii „normalnego kraju” (futsū no kuni $)^{29}$.

W 1994 r. osiem partii koalicyjnych dokonało tego, co nie udało się PL-D przez 38 lat dominacji na japońskiej scenie politycznej: zniesiono system średnich okręgów wyborczych, zastępując go systemem mieszanym. 300 posłów miało być wybieranych w jednomandatowych okręgach wyborczych, zaś 200 (później ich liczbę zmniejszono do 180) - wchodzić do parlamentu zgodnie z zasadą proporcjonalności, według wcześniej przygotowanych list partyjnych dla 11 dużych okręgów. Oczekiwano, że nowy system podważy hegemonię PL-D i spowoduje stopniowe zniknięcie charakterystycznej dla niej frakcyjności. Równocześnie zmieniono zasady zbierania funduszy partyjnych. Ostatecznie zakazano dokonywania wpłat na rzecz pojedynczych polityków przez grupy zorganizowane czy firmy i pozwolono im tylko na datki na rzecz partii. Wprowadzono także subsydiowanie partii ze środków państwowych. Zwiększyło to oczywiście kompetencje centralnych władz PL-D kosztem jej frakcji. Pojedynczy politycy nadal mogą otrzymywać pieniądze od osób prywatnych, ale tylko do 1,5 mln yenów rocznie.

Tymczasem w pozbawionej władzy PL-D międzyfrakcyjna rywalizacja straciła na znaczeniu. Zniknął wszakże bodziec, który ją podsycał, czyli walka o rozdział stanowisk państwowych. Pozostały stanowiska partyjne, ale w ugrupowaniu opozycyjnym nie miały one już takiego splendoru, jak dawniej. Widząc potrzebę reformy, która umożliwiłaby powrót do władzy, wybrano na przewodniczącego Kōno Yōhei'a z liberalnej frakcji Kōchikai ${ }^{30}$. W 1994 r. po raz kolejny w historii ogłoszono rozwiązanie frakcji w PL-D i przez jakiś czas rzeczywiście zdawało się, że ich aktywność zamarła. W 1996 r. okazało się jednak, iż pozostawały one tylko „w stanie uśpienia”, by odtworzyć swoje struktury przy okazji powołania rządu przez Hashimoto Ryūtarō, który na dobre przywrócił PL-D do władzy.

${ }^{27}$ Ibidem, s. 73-76.

${ }^{28}$ Honzawa Jirō, Ura kara..., s. 147.

29 Ibidem, s. 102-103.

${ }^{30}$ Co ciekawe, Kōno Yōhei jest synem Kōno Ichirō, niegdysiejszego przywódcy jednej z najbardziej prawicowych frakcji w PL-D. Po aferze firmy Lockheed Kōno Yōhei opuścił PL-D, zakładając Nowy Klub Liberalny (Shin Jiyū Kurabu) i żądając gruntownej odnowy wewnątrz partii. W 1985 r. jednak powrócił do PL-D. 


\section{Frakcyjność w PL-D dzisiaj}

Obecnie w PL-D istnieje dziewięć frakcji, które wywodzą się z systemu pięciu dużych frakcji z lat 80 . W następnej dekadzie rywalizacja o władzę i reforma systemu wyborczego sprawiły, że frakcje ulegały kolejnym podziałom, ale były w stanie przetrwać, adaptując się do nowych warunków. Wobec utrzymania się frakcyjności w PL-D, pomimo usilnych prób jej wyeliminowania, należy zadać pytanie, czy reformy z 1994 r. w ogóle wpłynęły na osłabienie potęgi grup wewnątrzpartyjnych? Analizy tej można dokonać, biorąc pod uwagę erozję poszczególnych funkcji frakcji, czyli zarządzania funduszami, mobilizacji poparcia wyborczego oraz obsadzania stanowisk partyjnych i państwowych.

Zdaje się, że w wyniku zmiany zasad finansowania partii rola frakcji polegająca na zarządzaniu funduszami rzeczywiście zmalała. Zamiast bezpośrednio wypłacać swoim członkom pieniądze, frakcje wymagają teraz od polityków pozyskiwania funduszy w wielkości proporcjonalnej do pełnionego stanowiska. W porównaniu z przeszłością, środki rozdzielane między członków frakcji mają charakter symboliczny $^{31}$. Zmiany wymuszone przez nowe ustawodawstwo mogą się jednak okazać iluzoryczne. Frakcje do perfekcji opanowały sztukę adaptacji do nowych warunków. Chociaż nie wolno już dokonywać dużych wpłat na rzecz poszczególnych polityków, pozostawiono jednak możliwość wpłacania pieniędzy do lokalnych oddziałów PL-D. Ponieważ szefami takich oddziałów są politycy, filie PL-D zaczęły po prostu pełnić funkcję osobistych kōenkai ${ }^{32}$ poszczególnych kandydatów ${ }^{33}$. Rola frakcji sprowadza się dzisiaj do dystrybucji ,zaufania”, a nie bezpośrednio pieniędzy od przywódcy do szeregowych parlamentarzystów. Tworzona jest swoista sieć lokalnych oddziałów, opanowanych przez członków poszczególnych frakcji, którzy opierając się na renomie swoich patronów, mogą skuteczniej przyciągać kapitał ${ }^{34}$.

Wprowadzenie jednomandatowych okręgów wyborczych zdawało się usunąć główną przyczynę frakcyjności w PL-D, czyli konieczność rywalizacji między kandydatami partii w tym samym okręgu. Okazało się jednak, że sama zmiana ordynacji wyborczej nie wystarczy do eliminacji scementowanych silną solidarnością grup wewnątrzpartyjnych. W efekcie reformy promowanie młodszych kolegów

${ }^{31}$ Cheol Hee Park, Factional dynamics in Japan's LDP since political reform. Continuity and change, „Asian Survey” 2001, vol. XLI, nr 3, s. 435-440.

${ }^{32}$ Kōenkai są organizacjami, utrzymującymi kontakty pomiędzy poszczególnymi politykami PL-D a wyborcami z ich okręgów wyborczych.

33 Tsuchiya Shigeru, op.cit., s. 72.

${ }^{34}$ Ibidem, s. 79-80. 
przez frakcyjnych seniorów w czasie kampanii wyborczej zamieniło się w presję wywieraną na centralne organy PL-D, aby kandydat danej frakcji uzyskał oficjalną nominację partyjną. Poza tym nie ziściła się nadzieja, że kandydaci poszczególnych partii w jednomandatowych okręgach będą prowadzić kampanie nastawione na program polityczny, a nie na osobiste związki z określonymi grupami wyborców. Przed pierwszymi wyborami według nowej ordynacji w 1996 r. w wielu regionach doszło wręcz do „handlu” wiernym elektoratem, który został odcięty od swojego kandydata z powodu zwiększenia ilości okręgów wyborczych.

Związi polityków PL-D z tradycyjnymi grupami społecznymi zostały za to osłabione za pięcioletniej kadencji Koizumiego Jun'ichirō (2001-2006). Ten charyzmatyczny premier mógł dzięki własnej popularności siłą narzucać decyzje polityczne całej PL-D, tępiąc przy tym wewnątrzpartyjną opozycję. Członkowie parlamentu, którzy sprzeciwili się prywatyzacji poczty w 2005 r., zostali wyrzuceni z partii i pozbawieni oficjalnej nominacji PL-D w wyborach parlamentarnych. Na miejsce takich buntowników Koizumi niejednokrotnie wyznaczał na kandydatów „nowe twarze” ze świata mediów. Czas jednak pokaże, czy następcy Koizumiego będą w stanie prowadzić równie zdecydowaną politykę. W dużym stopniu będzie to zależeć od ich popularności w społeczeństwie. PL-D pod przewodnictwem Abe Shinzō poniosła 29 lipca 2007 r. klęskę w wyborach do izby wyższej parlamentu. Wyraźne zwycięstwo Japońskiej Partii Demokratycznej pod przewodnictwem Ozawy Ichirō unaoczniło potrzebę dalszego zaostrzenia zasad finansowania partii, ale przede wszystkim nasiliło w PL-D głosy przeciwstawiające się dyktatorskim metodom sprawowania władzy przez premiera. Paradoksalnie, ale tym razem klęska wyborcza mogła być wynikiem osłabienia frakcyjności za kadencji Koizumiego. Rywalizacja między frakcjamo tradycyjnie dodawała wszakże PL-D dynamiki. Koizumi potrafił zastapić tę mobilizacyjną rolę frakcji własną charyzmą której jednak pozbawiony był Abe. Możliwe więc, że za kadencji premiera Fukudy Yasuo nasili się nurt przywrócenia wpływów frakcji jako gwarancji nieustającej władzy PL-D.

Za kadencji premiera Moriego (2000-2001) znaczenie funkcji rozdziału stanowisk nie zostało w równym stopniu osłabione, jak za jego dwóch poprzedników, jest zaś ona na tyle istotna, że może stanowić główny sens istnienia grup wewnątrzpartyjnych. Bardziej widoczne zmiany nastapiły jednak za rządów trzech ostatnich premierów. Koizumi Jun'ichirō doszedł do władzy, głosząc hasła osłabienia czy wręcz zniesienia frakcyjności w PL-D. Zapowiadał m.in., że jego rząd będzie rząadem ludzi kompetentnych, a nie mianowanych według klucza frakcyjnego ${ }^{35}$. Sam sposób elekcji Koizumi'ego na stanowisko szefa partii nosił znamio-

${ }^{35}$ Itagaki Eiken, Sengoku Jimintō 50 nen shi-Kenryoku tōsōshi [50 lat walczących państw Partii Liberalno-Demokratycznej - Historia walki o władzę, Kadensha, Tokio 2005, s. 189. 
na nowych czasów. Koizumi Jun'ichirō wygrał rywalizację z Hashimoto Ryūtarō w 42 z 47 prefekturalnych oddziałów partii, posiadających po 3 głosy. Co ważne, w przeciwieństwie do prawyborów z 1978 r., zawdzięczał to nie tyle frakcyjnym powiązaniom, co poparciu szeregowych członków PL-D, którzy postrzegali w nim polityka ,poza układami” ${ }^{36}$. Po takiej demonstracji siły parlamentarzystom nie wypadało już głosować na Hashimoto, który był początkowo uważany za faworyta wyborów. W 2001 r. premier Koizumi demonstracyjnie nie konsultował swych decyzji w sprawie obsadzenia ministerstw z przywódcami frakcji, choć musiał się uciec do tej tradycyjnej praktyki w przypadku pozostałych istotnych stanowisk, np. wiceministrów czy przewodniczących komisji parlamentarnych ${ }^{37}$. Przez całą pięcioletnią kadencję dużo energii poświęcił systematycznemu niszczeniu wpływów szefów frakcji, posuwając się nawet do stwierdzenia, że zniszczy frakcje, choćby miał zniszczyć partię. Symbolicznym posunięciem był wybór w 2003 r. Abe Shinzō na stanowisko sekretarza generalnego partii wbrew niepisanej zasadzie, że osoba piastująca ten urząd powinna wywodzić się z innej frakcji niż przewodniczący partii ${ }^{38}$.

Z kolei Abe Shinzō, już jako premier, zapowiadając kontynuację reform swego poprzednika, powołał w 2006 r. rząd bez negocjacji z szefami frakcji i nominował kolegę frakcyjnego Nakagawę Hidenao na nowego sekretarza generalnego partii ${ }^{39}$. Jednakże kolejne gabinety siłą rzeczy musiały odzwierciedlać rozkład sił wewnątrz partii. W 2007 r., przy okazji wygranych przez Fukudę Yasuo wyborów na przewodniczącego PL-D, media japońskie szeroko komentowały poparcie poszczególnych frakcji dla danych kandydatów. Poglądy Fukudy Yasuo na temat frakcyjności przypominają dążenia jego ojca. O ile jednak Fukuda Takeo sprawował władzę w latach 70., nazywanych ,złotym okresem frakcji”, o tyle Fukuda Yasuo ma prawo podkreślać z zadowoleniem, że: Obecnie to już nie sa frakcje. Jeśli nawet nazywa sie je frakcjami, nie ma potrzeby myśleć o nich jako o czymś podobnym, ponieważ spetniane przez nie funkcje różniq się od funkcji dawnych frakcji. Niegdyś mury pomiędzy frakcjami byty bardzo wysokie, w żaden sposób nie byto się w stanie ich przekroczyć. (...) Dzisiaj można się swobodnie gromadzić,

${ }^{36}$ Koizumi zwyciężył jednak także dzięki rezygnacji w ostatniej chwili Kamei Shizuki i wsparciu uzyskanemu ze strony jego frakcji. Również i tutaj nie obyło się więc bez pewnych „zagrywek” międzyfrakcyjnych.

${ }^{37}$ Patrick Köllner, Factionalism in Japanese political parties revisited or how do factions in the LDP and the DPJ differ?, „Japan Forum” 2004, vol. 16, nr 1, s. 94.

38 Zasada ta została ustanowiona w latach 70. XX w.; uprzednio sekretarz generalny PL-D pochodził zazwyczaj z frakcji przewodniczącego. Szerzej na ten temat: Iseri Hirofumi, op.cit., s. 136-142.

39 LDP exec lineup heavy on reform, „The Asahi Shimbun” 26 IX 2006, [@:] http://www.asahi. com/english/Herald-asahi/TKY200609260126.html, dostęp: 31 XII 2006 r. 
rozmawiać, naradzać czy uczyć polityki na poziomie ponadfrakcyjnym ${ }^{40}$. Co prawda dopiero przyszłość pokaże, czy spełniana przez frakcje funkcja rozdziału stanowisk rzeczywiście dozna takiej samej erozji, jak funkcja mobilizacji poparcia wyborczego i pozyskiwania funduszy. Będzie to w dużym stopniu zależało od charyzmy przyszłych przewodniczących PL-D.

\section{Podsumowanie}

Wewnętrzna reforma Partii Liberalno-Demokratycznej stała się jednym z naczelnych tematów dyskusji pomiędzy politykami tego ugrupowania już niedługo po jej utworzeniu w $1955 \mathrm{r}$. Celem proponowanych zmian stało się przede wszystkim zniesienie frakcyjności, utożsamianej z przyczyną korupcyjnych powiązań ze światem biznesu. Chociaż prób reformy podejmowali się także politycy powszechnie uważani za „czystych”, jak Miki Takeo czy Kōno Yōhei, to zazwyczaj retoryka rozwiązania frakcji służyła za narzędzie walki międzyfrakcyjnej. Zwolennikami zniesienia wewnątrzpartyjnych podziałów byli głównie przewodniczący PL-D, pragnący umocnić własną władzę i stłumić wewnątrzpartyjną krytykę. Niejednokrotnie za takimi działaniami stały, jak w przypadku Kishiego Nobusuke, bardziej dalekosiężne cele, jak zmiana konstytucji czy remilitaryzacja kraju.

Osłabienie frakcyjności w PL-D za rządów Koizumiego Jun'ichirō ma pod wieloma względami głębszy charakter niż próby reformy w przeszłości. Zmiana ordynacji wyborczej w 1994 r., choć nie przyniosła wyráznych natychmiastowych nastepstw, stworzyła podstawy do zdestabilizowania systemu frakcyjnego. Koizumi Jun'ichirō z jednej strony pokazał, że silny przywódca PL-D może wykorzystać osłabienie spełnianych przez frakcje funkcji zarządzania funduszami i mobilizacji poparcia wyborczego do tego, by zakwestionować także funkcję rozdziału stanowisk, stanowiącą sens ich istnienia. $Z$ drugiej zaś - frakcje przetrwały trudne czasy pięcioletniej kadencji Koizumiego i przyszłość pokaże, czy uda się je rzeczywiście ,wytępić”. Trzeba także być świadomym tego, że zniesienie frakcji przy braku charyzmatycznego przywódcy może oznaczać zakwestionowanie dominacji PL-D na japońskiej scenie politycznej, a trudno sobie wyobrazić, by jakakolwiek partia świadomie działała na własną szkodę.

${ }^{40}$ Fukuda Yasuo, Etō Seishirō, Ikkoku wa hitori o motte okori, hitori o motte horobu [Kraj kwitnie dzięki jednostce i przez jednostkę jest niszczony], KK Bestoserāzu, Tokio 2007, s. 165. 